\title{
Sol-Gel Technology in Enzymatic Electrochemical Biosensors for Clinical Analysis
}

\author{
Gabriela Preda, Otilia Spiridon Bizerea and Beatrice Vlad-Oros \\ West University of Timişoara, Faculty of Chemistry-Biology-Geography, \\ Department of Chemistry, Timişoara, \\ Romania
}

\section{Introduction}

Enzymes are without question the most powerful, versatile and efficient, wide-spread biocatalysts in the biological world, being responsible for remarkable reaction rate enhancements. Enzymes are also very specific, able to discriminate between substrates with quite similar structures. They exhibit different types of selectivity (chemo-, enantio-, regioand diastereoselectivity) and can catalyse a broad range of reactions. Moreover they are environmentally friendly, acting under mild conditions. They are used in many biotechnological domains, as isolated enzymes or whole cells, in free or immobilized form. The dual character of an enzyme, as both protein and catalyst, brings face to face the special properties of proteins like activity, selectivity, inhibition phenomena, unfolding in a harsh environment with the need for stability, reproducibility, long term reusability of the catalyst. The catalytic activity of enzymes depends on the integrity of their native protein conformation. If an enzyme is denatured or dissociated into its subunits, catalytic activity is usually lost. Thus the primary, secondary, tertiary, and quaternary structures of protein enzymes are essential to their catalytic activity. Therefore, enzymes cannot be used at high temperature, extreme $\mathrm{pH}$ or high ionic strength, operation parameters that could lead to enzyme deactivation. Another issue that limits the efficiency of the enzymatic reactions is the substrate or product inhibition - the enzyme stops working at higher substrate and/or product concentration (Chibata, 1978; Smith, 2004).

So, reliable techniques for protein stabilization are of great practical importance (Rothenberg, 2008). Enzymes in biosensors are used in an "immobilized" form. Even though at the beginning of the $21^{\text {th }}$ century immobilization of biomolecules may be at a first glance a solved problem, reality shows that work has yet to be done in order to obtain stable, longliving robust and active biocatalysts, even if they are isolated biomolecules (enzymes, proteins, nucleic acids), whole cells or other biological species.

A lot of immobilization methods are available. Among them, sol-gel technology application in biosensing has been of great interest in the last two decades. Sol-gel technology (Brinker \& Scherer, 1990) opens a simple route to produce materials like glasses, monoliths, powders, thin films in mild conditions. Inorganic and hybrid organic-inorganic micro and nanostructered matrices based mainly on silica gels will be briefly described. Enzymes 
entrapment in silica gels by sol-gel route is now history (Avnir et al., 1994; Gill \& Ballesteros, 2000; Livage et al., 2001; Retz et al., 2000). Application of sol-gel technique in biosensing has been a logical consequence (Kunzelmann \& Bottcher., 1997; de Marcos et al., 1999; Wang, 1999). In recent years, the research has been focused on new sol-gel-derived materials to make the network more compatible with the biomolecules (Gupta \& Chaudhury, 2007; Smith et al., 2007). The most important applications are in biocatalysis and biosensing, in clinical, environmental, food or process analysis. Till 1992, about 3000 enzymes have been recognized by The International Union of Biochemistry, but only a small percent of them is commercially available, so the potential of these powerful biocatalysts is not fully exploited remaining that future research to increase their use (Faber, 2000).

This chapter will focus on enzyme biosensors with application in clinical analysis, mainly on glucose sensing based on glucose oxidase. Why glucose sensing? Why glucose oxidase? More than $60 \%$ of research in biosensors is focused on this analyte and this enzyme (Newman \& Turner, 2005; Yoo \& Lee, 2010). Glucose/glucose oxidase system could be, no doubt, a case study. The enzyme is very "suited" for sensing, accessible, with very high specificity, versatile and, most of all, the subject is of tremendous public importance.

\section{Biosensors - short overview}

\subsection{Concepts and definitions}

In a modern, suggestive and concise context, a biosensor is a sensor that incorporates a biological sensitive element, i.e. an analytic device that converts a biological response in an analytical signal (Velusamy et al., 2010). In a larger acceptation, a biosensor can be defined as a compact, self-contained, reversible, integrated bioanalytical device, having a biological sensitive component or a biological derivative directly connected to a compatible physicochemical transducer. Together, they transpose the concentration of a certain analyte or a group of similar analytes, in a measurable response, and are connected to a processor of the provided electronic signal (Matrubutham \& Sayler, 1998; Rogers \& Mascini, 2009; Sing \& Choi, 2009; Thévenot et al., 1999; Turner et al., 1987; Urban, 2009).

According to the standard definition given by the International Union of Pure and Applied Chemistry (IUPAC), a biosensor is an integrated self-contained receptor-transducer device, able to provide selectively quantitative or semi-quantitative analytical information using a biologic recognition element, which is in direct spatial contact with a transducer element (Justino et al., 2010; Thévenot et al., 1999), or a device based on specific biochemical reaction catalyzed by isolated enzymes, immunosystems, tissues, organelles, or whole cells to detect chemical compounds, usually by electric, thermal or optical signals, respectively (Nayak et al., 2009).

A biosensor can be schematically presented as in Figure 1 considering that integrates a biological recognition element (bioreceptor) with a physicochemical transducer generating a measurable electronic signal, proportional with the concentration of the determined analyte, which is then amplified, processed and displayed (Belkin, 2003; Lei et al., 2006; Su et al., 2010; Wilson \& Gifford, 2005).

\subsection{Components}

It is already known, that biosensors are composed of two main components connected in series: a molecular recognition system (biorecognition element or biocatalyst generically called bioreceptor) that detects the analyte of interest intimately connected or integrated to a 
physicochemical transducer (detector), converting the spot target in a measurable electric signal (Bergveld, 1996; Justino et al., 2010; Singh \& Choi, 2009; Tothill, 2009; Velusamy et al., 2010). The biological recognition element of a biosensor is a molecular species that uses a specific biochemical mechanism, mediated by enzymes, nucleic acids, antibodies, cellular systems, microorganisms etc., to detect the target analyte from biological samples. The biorecognition elements can be classified in two broad categories: bioligands (antibodies, nucleic acids, lectins etc.) and biocatalysts (enzymes, hormones, vitamins, microorganisms, tissues etc.). The bioligands are responsible for binding the considered analyte to the biosensor, for detection and measurement of the target compounds from the sample, usually by transforming them in an electric, thermal or optical signal. Biocatalysts are substances with activating role in biological reactions, in the transformation of substrates to products. After the interaction with target species, the physicochemical properties of the sensitive layer (weight, optical properties, resistance) are changed. The modified parameter is taken over by the transducer and converted in an equivalent, measurable electrical signal which is then amplified. The amplified signal, proportional with the concentration of the substance or set of analyzed substances, is processed by a signal processor that provides a digital electronic signal which can be saved, displayed and analyzed with a proper hardware and software (Castillo et al., 2004; Justino et al., 2010; Singh \& Choi, 2009; Velusamy et al., 2010).

Many biological recognition elements, which provide the specificity and sensitivity required to sense low levels of the sample analyte, are used as bioreceptors to detect bioanalytes such as: enzymes, hormones, vitamins, proteins, nucleic acids, antibodies/antigens, whole cells from superior organisms, tissues, organelles, liposomes, bacteria, viruses, other microorganisms, cofactors, biomimethics etc. (Singh \& Choi, 2009; Su et al., 2010; Tothill, 2009; Velusamy et al., 2010;).

The transducer can be electrochemical (i.e. ion-selective electrodes), heat sensitive (i.e. calorimetric), piezoelectric (i.e. acoustic sounds), optical (i.e. optical fibers), magnetic and micromechanical or any other combination of these (Velusamy et al., 2010).

The bioreceptor is responsible for the selectivity and specificity of biosensor towards a certain analyte. The detector is not selective but has a great influence on the sensitivity of the biosensor.

Very often, optimal functioning of biosensors requires the presence of an intermediate compound, called mediator, which shuttles redox equivalents between bioreceptor and transducer. Depending on the type of contact and integration level of biological recognition element and transducer, biosensors have mainly known three generations of development. First generation of biosensors have the biorecognition element physically bound or entrapped into a membrane fixed on the transducer surface. Electrochemical biosensors of this generation include only the biorecognition element and the transducer. Second generation of biosensors have the biologically active component directly adsorbed or covalently bound on the transducer surface without a semipermeable membrane. In this case, the diffusion of mediators, which are not immobilized on the transducer surface, may take place freely. In case of third generation of biosensors, the bioreceptor is directly bound on an electronic device which transforms and amplifies the signal. The biosensors based on conducting polymers belong to this category.

Even if, apparently, the difference between second and third generation of biosensors does not seem significant, setting up the whole sensing chemistry on the transducer surface is a complex task. Generally, the methods utilized to immobilize biomolecules on the electrode surface are used also for redox mediators (e.g. adsorption, covalent binding to conducting or non-conducting polymer backbones, mixing with the electrode material (e.g. carbon paste) 
or entrapment into a polymeric matrix by ion exchange) to ensure a suitable electron transfer pathway (Castillo et al., 2004; Singh \& Choi, 2009).

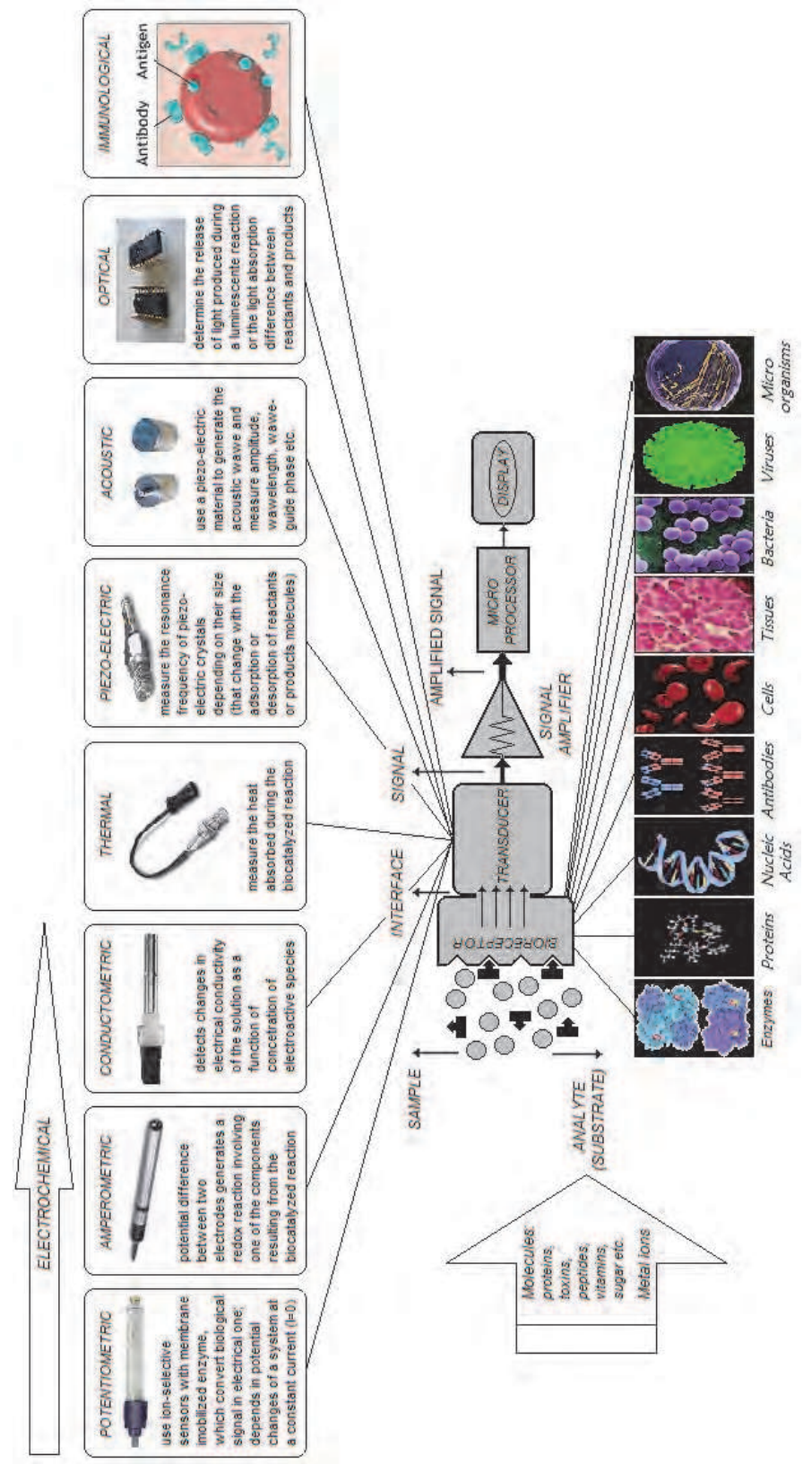

Fig. 1. Biosensor device 
The analyte molecules may comprise proteins, toxins, peptides, vitamins, sugars, metal ions etc. The most common signalling principles/elements can be electrons, ions (voltammetry, potentiometry, conductivity), protons - $\mathrm{pH}$ changes, optical (SPR, ELM, IR), electromechanical (QCM), magnetic, heat, pressure, light, mass variation, fluorescence. Response variables can be: the potential, current, frequency, mass, temperature and pressure, respectively. Typical sensing techniques for biosensors are fluorescence, DNA microarray, Surface Plasmon Resonance (SPR), impedance spectroscopy, Scanning Probe Microscopy (SPM, AFM, STM), Quartz Crystal Microbalance (QCM), Surface Enhanced Raman Spectroscopy (SERS), electrochemical.

\subsection{Classification}

Biosensors can be classified according to many criteria, out of which we mention the followings:

- the bioactive/bioreceptor material

- $\quad$ the transducer

- the immobilization technique.

In general, the bioreceptors or the recognition biological materials can be classified in five major classes, as it is shown in Figure 2. The enzymes, antibodies and nucleic acids are the main bioreceptor classes that are mostly used in biosensors applications. In general, they are immobilized on a support which can be the detector surface, its vicinity or a transporter (Ivnitski et al., 2000; Lazcka et al., 2007; Oh et al., 2005; Radke \& Alocilja, 2005; Velusamy et al., 2010).

The biosensors classification according to the nature of the variable parameter converted by the transducer in electric signal can be seen in Figure 1, but a more complete classification is given in Figure 3.

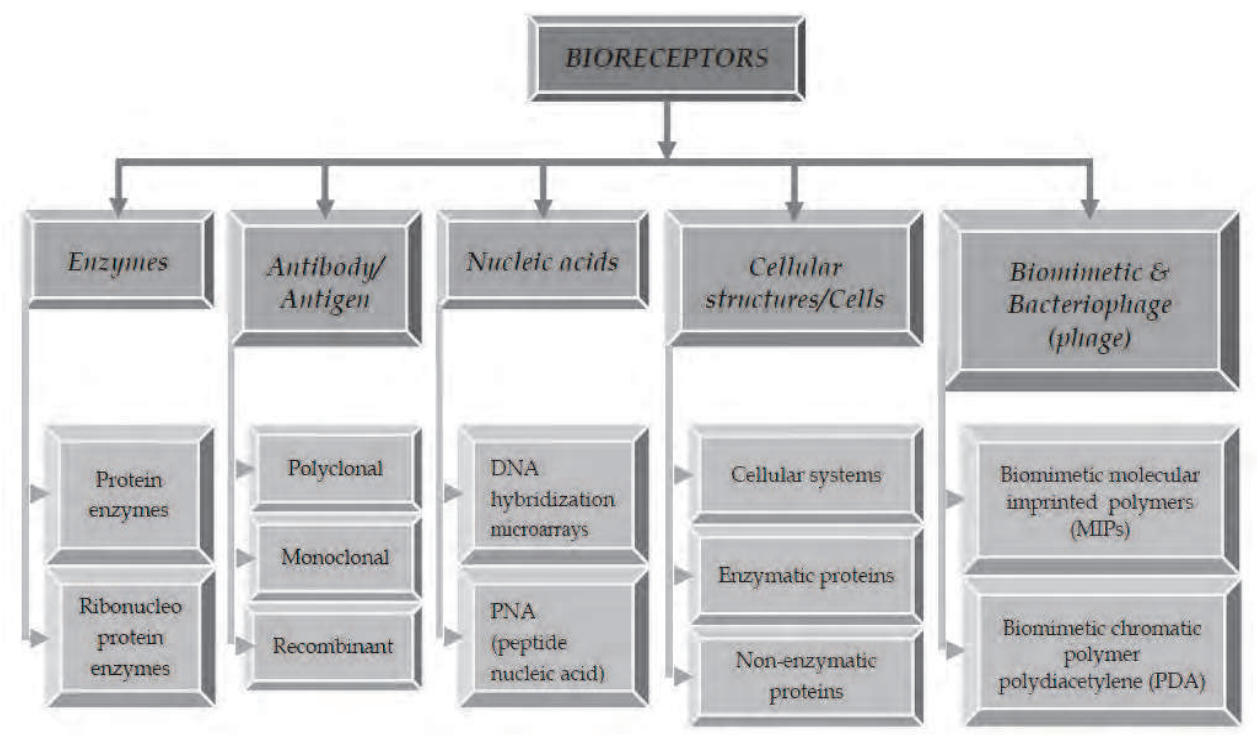

Fig. 2. Biosensors classification according to the bioreceptor type 


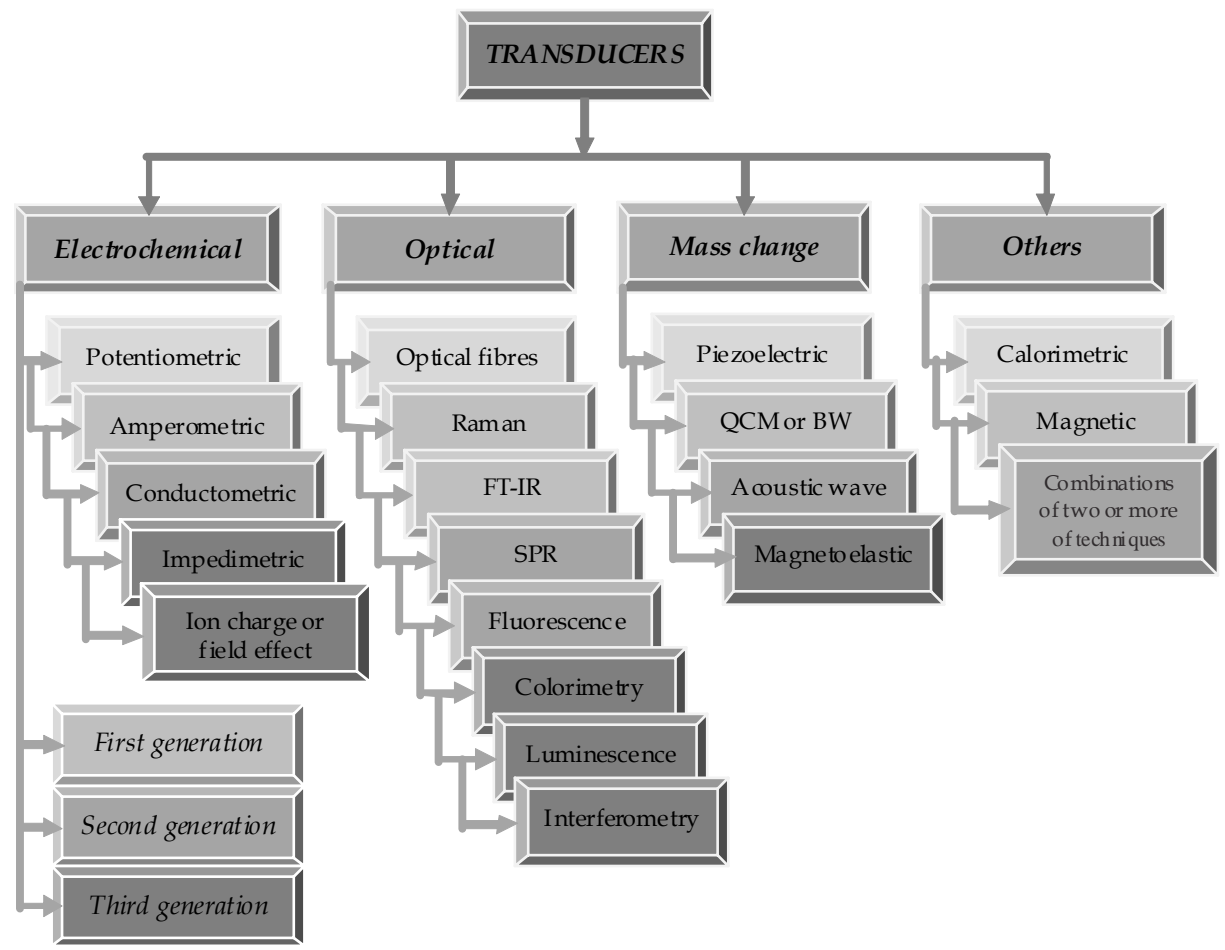

Fig. 3. Biosensors classification according to the transducer type

During the biochemical transformation, the modified parameters that can be detected with the electrochemical transducer are: electric current, potential, impedance and conductance.

Optical transducers are based on the optical properties of the substances, as: absorption, reflection, refraction, light scattering, fluorescence, chemiluminescence, phosphorescence etc. Due to their sensitivity, the most used optical detection techniques are Raman and Fourier Transform Infrared Spectroscopy (FT-IR), Surface Plasmon Resonance (SPR) and Fluorescence. The most used types of biosensors are amperometrical, potentiometrical and optical ones. The foremost methods based on mass exchanges detected with biosensors transducer, depend on the use of piezoelectric crystals. The two major types of sensors based on mass variation are Bulk Wave (BW), also called Quartz Crystal Microbalance (QCM), and Surface Acoustic Wave (SAW), respectively (Velusamy et al., 2010).

\subsection{Biosensors mechanisms}

According to the interaction mechanism, three types of biosensors can be identified: 1. biocatalytic (enzymatic/metabolic) biosensors (the recognition element is represented by enzymes); 2. biosensors that act based on bioaffinity or biocomplexation (based on recognition mechanisms with antibodies, nucleic acids, lectins etc.). 3. biosystems based on microorganisms. (Rogers \& Mascini, 2009; Thévenot et al., 1999).

In case of biocatalysis, biorecognition reaction is catalyzed by macromolecules that can be present in a biologic environment or have been previously isolated. The substrate interacts 
with the immobilized biocatalyst on the sensor (surface), then a biocatalyst-substrate complex is formed and after the reaction takes place, the product is released and the catalyst is regenerated. The substrate consumption or the product release is continuously measured and the biological response is converted into an electrically quantifiable signal monitored by the integrated detector of the biosensor. These types of biosensors (biocatalytic sensors) usually use enzymes, whole cells (cellular microorganisms as bacteria, fungi etc.), cellular organelles (mithocondria, cell walls) or tissues (vegetal or animal). Generally, biocatalysts based biosensors depend on the use of enzymes. These biological catalysts can be comprised in one of the six classes: oxidoreductases (dehydrogenases, oxidases, peroxidases, oxygenases), transferases, hydrolases, lyases, isomerases and ligases. Biocatalysis underlying mechanisms involve either the catalytic conversion of an analyte from an undetectable form in a detectable one or the detection of an analyte that inhibits or mediates the enzymatic activity (Rogers \& Mascini, 2009; Thévenot et al., 1999).

In case of bioaffinity, operation of biosensors relies on selective interactions between the analyte of interest and biomolecules or organized molecular assemblies, either (present) in their biological environment or previously isolated. After the biocomplexing reaction, equilibrium is achieved and the analyte is no longer consumed. The equilibrium responses are monitored by the integrated detector. The antibodies capacity to specifically recognize different molecular structures confers high selectivity to biosensors based on bioaffinity (Rogers \& Mascini, 2009; Thévenot et al., 1999; Velusamy et al., 2010).

The class of biosensors based on microorganisms is used for analytes that form a respiratory substrate. These can detect either biodegradable organic compounds measured as biological oxygen demand or respiration inhibition caused by the analyte of interest. The biosensors based on Genetically Modified Microorganisms (GMMs) recognize and report the presence of a specific analyte (Rogers \& Mascini, 2009).

\subsection{Functional characteristics}

The main functional characteristics of a biosensor are shown in Figure 4.

The assessment of the functionality of any biosensor must begin with its calibration. This is generally performed using standard solutions of the analyte followed by the plot of the steady-state response against the analyte concentration or its logarithm. Exceptions are the biosensors causing a continuous change in the concentration of the analyte standard solutions because they trigger a reaction that takes place throughout the measurement till the depletion of the substrate. An example is the glucose potentiometric biosensor based on glucose oxidase. In this case the biosensor monitors the ongoing reaction following the variation of a parameter which is continuously changing and, at time considered optimal, calibration curve is plotted. The value of the followed parameter at optimal time depends on the concentration of standard solution in which monitoring is made (Thévenot et al., 1999; Bizerea-Spiridon et al., 2010a; Bizerea-Spiridon et al., 2010b; Vlad-Oros et al., 2009;).

\subsection{Applications}

Biosensors represent a rocketed developing field, with an enormous potential in terms of detection and control of a large number of analytes with important applications in health, agriculture, food industry, environmental monitoring etc. With an annual growth rate estimated at $60 \%$ (Chaplin \& Bucke, 1990), biosensors and analytical techniques in which they are involved will play an increasingly important role in the future technology. Some of the 


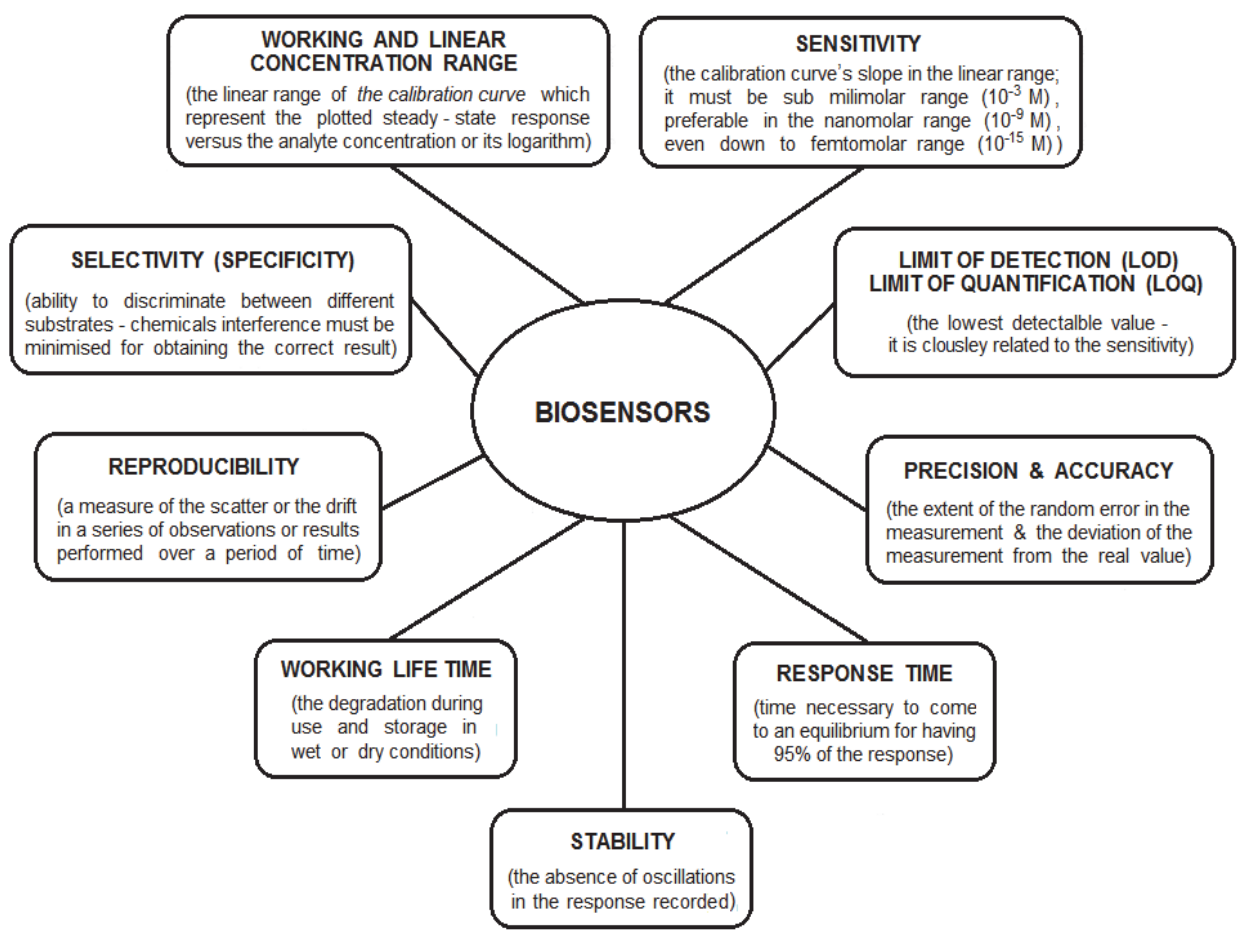

Fig. 4. The main functional features of a biosensor

most important applications of biosensors are presented in Table 1 (Castillo et al., 2004; Justino et al., 2010; Lazcka et al., 2007; Mello \& Kubota, 2002; Nayak et al., 2009; Rodriguez-Mozaz et al., 2005; Rodriguez-Mozaz et al., 2006; Rogers, 2006; Tothill, 2009; Verma \& Singh, 2005).

The recent progress in micro- and nanoscale technologies shows high promises in enabling a number of new applications in biosensing. Based on enzyme immobilization techniques, in the shape of capsules, beads, columns or membranes, many types of biosensors have been developed on a laboratory or even on a commercial scale (Rothenberg, 2008).

\section{Enzyme immobilization by sol-gel technique for biosensing applications}

\subsection{Fundamentals of enzyme immobilization for biosensing}

In vivo, nature produces enzymes when they are needed in the biochemical pathways. In vitro, in biocatalytic transformations, they have to be recovered and efficiently reused. This may be done by immobilization (Lalonde \& Margolin, 2002). Immobilized enzymes are defined as "enzymes physically confined or localized in a certain defined region of space with retention of their catalytic activities, and which can be used repeatedly and continuously" (Chibata, 1978).

In the last six decades, several methods of immobilization have been developed, starting with binding onto natural or synthetic carriers (Chibata, 1978), inclusion in organic or inorganic polymeric networks, or cross-linking, sometimes in the presence of inert molecules (Murty et al., 2002; Kennedy \& Cabral, 1987; Khan \& Alzohairy, 2010; Sheldon, 2007; Ullmann, 1987). 


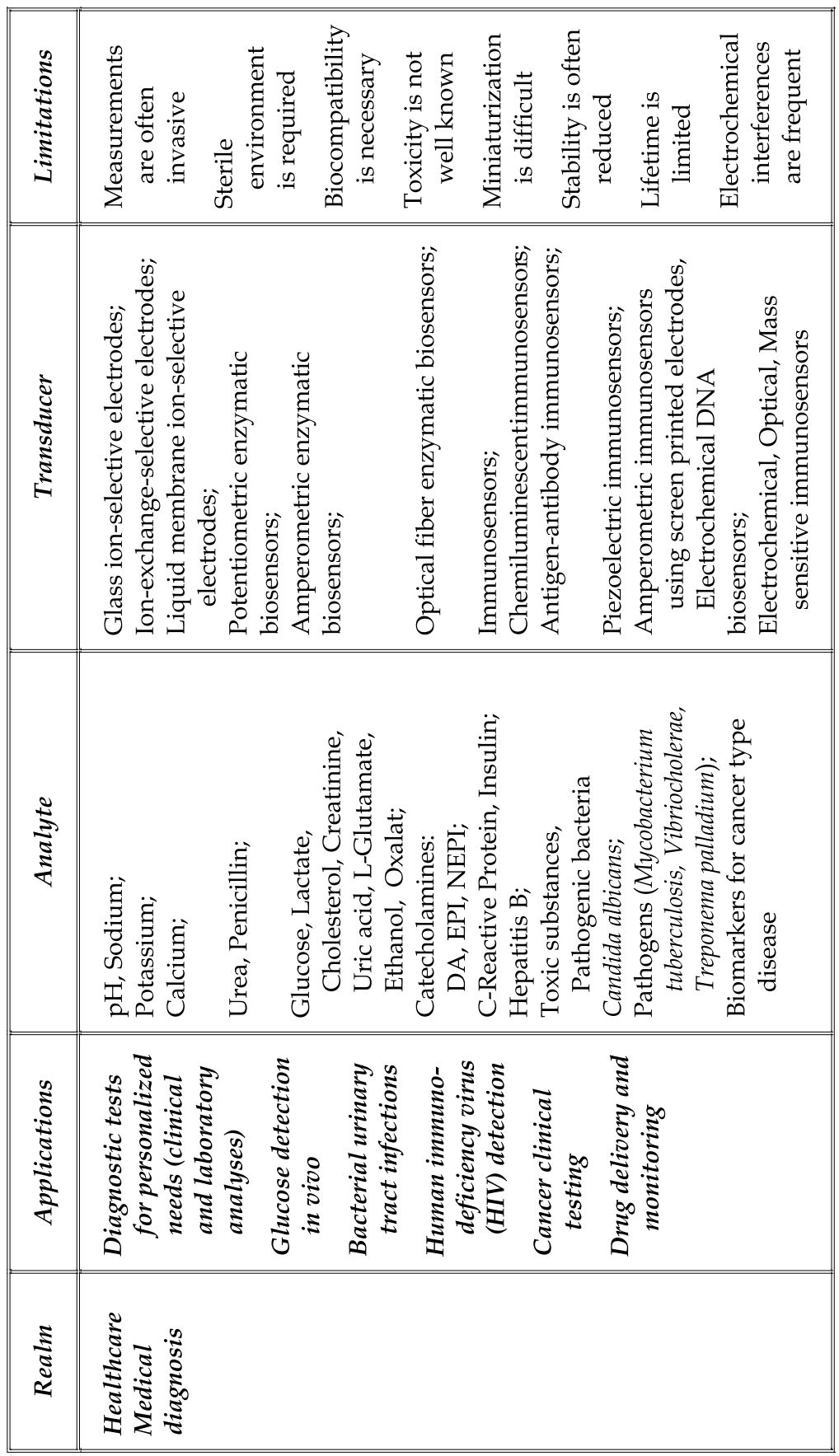

Table 1. Important domains for biosensors usage 


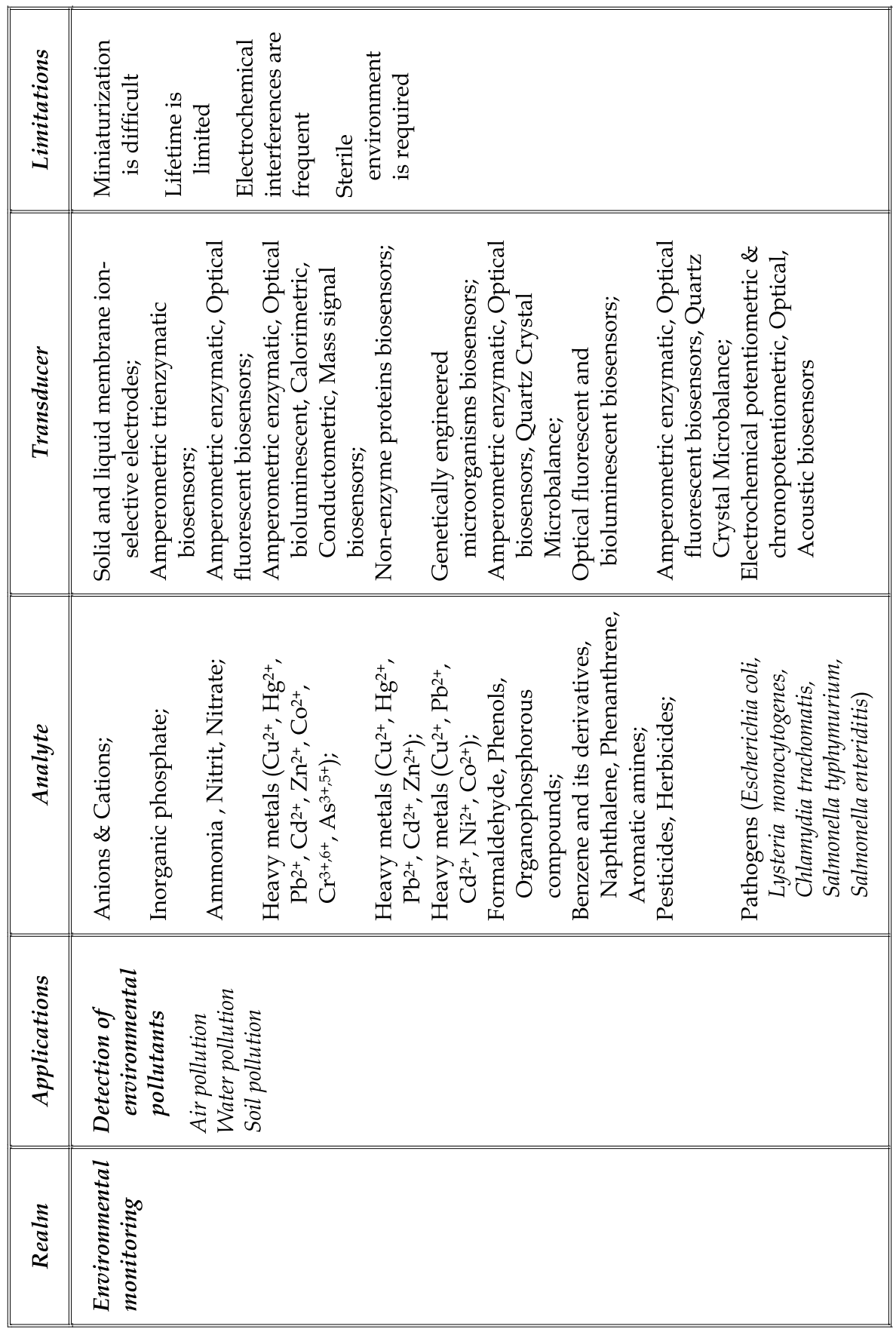

Table 1. Important domains for biosensors usage cont' 


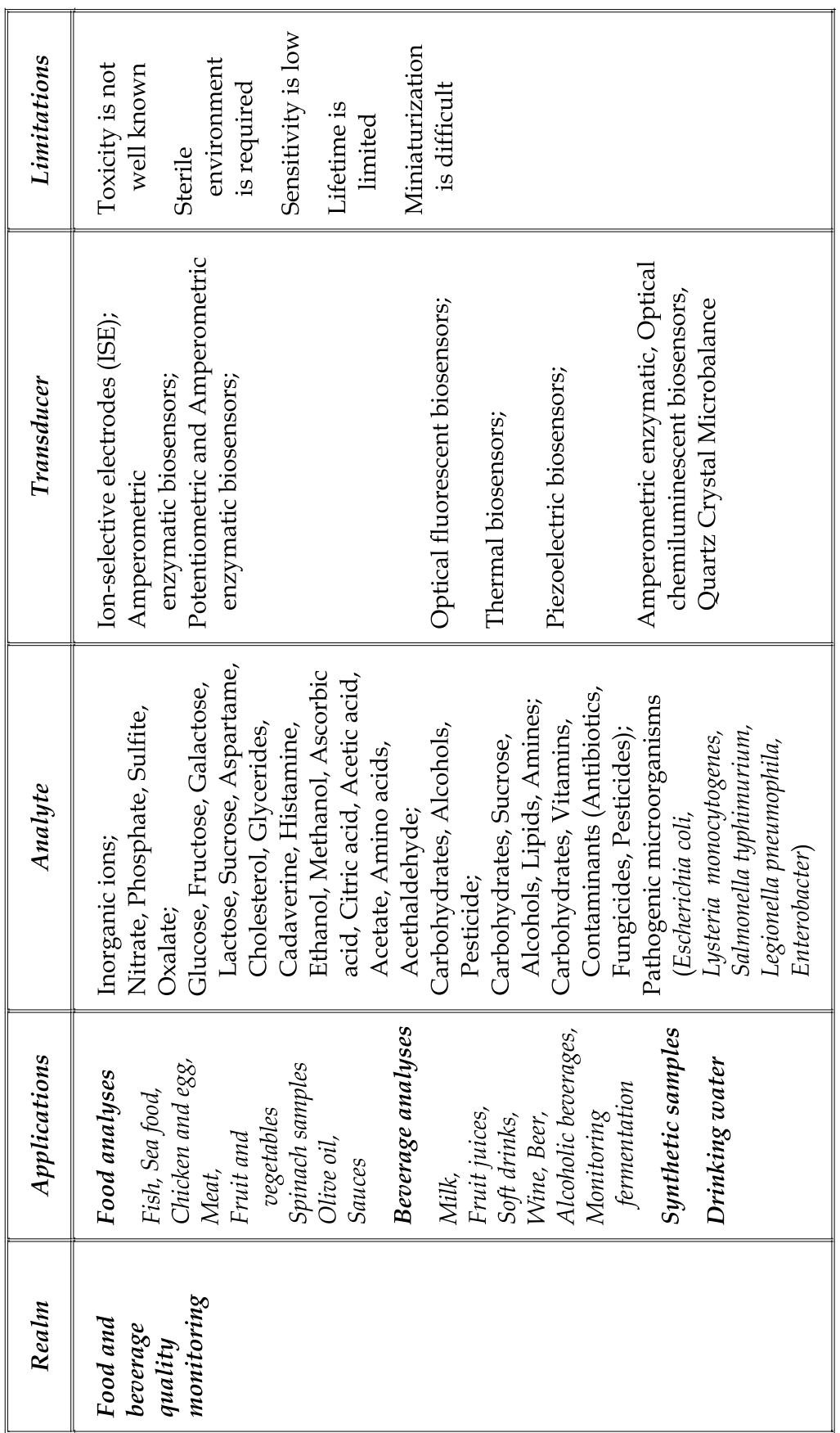

Table 1. Important domains for biosensors usage cont' 
For a successful immobilization procedure, three elements have to be considered: a) the enzyme, b) the support and c) the nature of enzyme binding to the support (Kennedy \& Cabral, 1987). The immobilization methods can be divided considering the interaction between enzyme and support in: a) physical binding or b) covalent binding to a solid carrier, c) entrapment in gel networks or d) cross-linking using (bi)functional agents (Smith, 2004).

These methods are widely used for enzymes immobilization. Physically, enzymes are adsorbed onto insoluble supports, entrapped within gel networks or encapsulated within microcapsules or in/behind semi-permeable membranes. Chemically, enzymes are either covalently bound to organic or inorganic carriers or cross-linked with functional agents.

In the physical binding the interaction between enzyme molecules and solid supports consists of stronger, ionic and hydrogen forces or weaker, van der Waals or hydrophobic forces, respectively. The physical methods are simple, inexpensive and usually they do not affect the catalytic activity of enzymes. The main disadvantage is the reversible binding of enzyme to the support (leading to enzyme leaching)(Lalonde \&Margolin, 2002; Smith, 2004).

The entrapment in a gel network is obtained by polymerization or precipitation/coagulation reactions in the presence of enzyme. The process is usually very simple, the enzymes structure is not affected, but sometimes activity loss may occur. The enzymes are captured in the pores network, while smaller or larger substrate or product molecules can diffuse throughout the gel towards/from the catalyst. If environmental changes disturb the porous network, enzyme leakage could happen. The diffusional limitations due to the polymeric matrix are usually problematic. A very important characteristic of entrapment is that it may be applied for cell fragments or even whole cells immobilization (Chibata, 1978; Lalonde \& Margolin, 2002; Smith, 2004).

In order to perform the coupling the enzymes by covalent binding to inorganic or organic, natural or synthetic carriers, a huge number of chemical reactions have been used (Kennedy \& Cabral, 1987; Sheldon, 2007). The most important advantage is that chemical binding, stronger than the methods previously described, leads to more stable biocatalysts. The covalent binding is non-specific and activity loss is observed if residues from the active site are involved.

Even though there is an enormous experience in the realm, it is obvious that no general rule is available to obtain active, stable, efficient, advanced immobilized biocatalysts with high yield and low costs. Stability vs. activity is a perpetual target in all applications.

An immobilized enzyme has to fulfil a sort of requirements for a good overall activity, such as reasonable immobilization yields, high activity and catalytic efficiency, high operational stability, limited mass transfer effect, easy handling and reusability (Bickerstaff, 1997; Khan \& Alzohairy, 2010; Krajewska, 2004; Sheldon, 2007).

Enzyme immobilization may change the kinetics and other properties essential for catalysis (optimum $\mathrm{pH}$ or temperature), usually with a decrease of the specific activity. An enhancement of enzymes stability ( $\mathrm{pH}$, thermal, storage and operational stability) upon immobilization is commonly observed - key advantage in enzyme immobilization (Mateo et al., 2007; Murty et al., 2002; Petkar et al., 2006).

The special characteristics of the immobilized enzymes have made them suitable for many applications in bioconversion processes or as biomaterials for health and biosensors (Coradin et al., 2006; Gupta \& Chaudhury, 2007; Khan \& Alzohairy, 2010; Kim et al., 2006; Li $\&$ Takahashi, 2000). The main techniques for enzymes immobilization applied to biosensors are shown in Figure 5. 


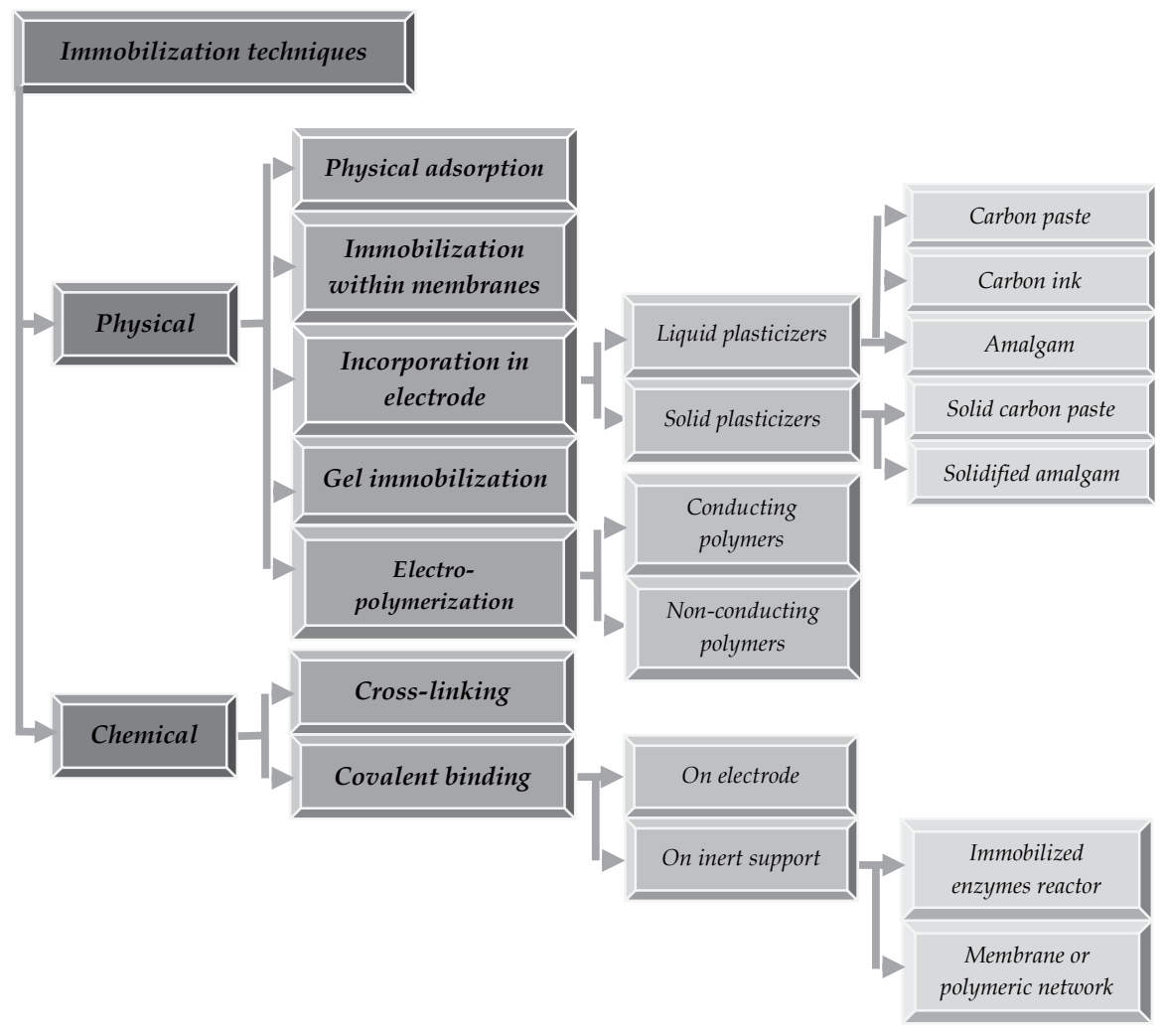

Fig. 5. Enzyme immobilization applied to enzymatic biosensors

In biosensing, immobilization is a key step in coupling of enzyme to electrode. The biosensor efficiency relies on solving problems such as: enzyme loss caused by the binding procedure, diminished availability of enzyme molecule within the carrier, slow diffusion of substrate molecules and active species within the pore network, good transfer of the chemical signal to the electrode. Furthermore, in biosensors, reproducibility, rapid answer, operational stability, enzyme molecule availability, kinetic parameters are essential for a good response (Coradin et al., 2006; Gupta \& Chaudhury, 2007; Khan \& Alzohairy, 2010; Kim et al., 2006).

\subsection{Sol-gel entrapment - a versatile tool for enzyme immobilization}

Although practice shows that a universal carrier is not known, some characteristics are desirable to any material considered for immobilizing enzymes: large surface area, hydrophilicity, permeability, insolubility, chemical, thermal and mechanical stability, resistance to microbial attack, etc. (Kennedy \& Cabral, 1987; Ullmann, 1987).

Gel entrapment of biomolecules is a well-established method for many years. Gels as agar, agarose, gelatin, alginate, chitin, chitosan, carrageenan or polyvinyl alcohol are highly biocompatible, accessible, easy to handle and largely used in very different applications. The most important disadvantages reside in their organic nature: some of them are mechanically fragile, cannot stand for biological attack or are highly toxic (Smith, 2004). 
Due to their physical properties, inorganic carriers have some important advantages over their organic counterparts: high mechanical strength, good thermal stability, high resistance to organic solvents and microbial attack, easy handling and regeneration. Inorganic supports are stable and do not alter their structure at environmental changes ( $\mathrm{pH}$ or temperature) (Coradin et al., 2006; Kennedy \& Cabral, 1987; Ullmann, 1987).

This chapter will deal with immobilization of enzymes using inorganic carriers. In order to make them compatible with organic and bio-molecules, mild synthesis methods are needed. Sol-gel synthesis of inorganic gels in conditions as harmless as possible is such an option. Silica sol-gel materials have been developed starting with the 1990's as a versatile and viable alternative to classical immobilization methods (Avnir et al., 1994; Reetz et al., 2000, Reetz et al., 2003). The sol-gel synthesis of silica gels is a chemical synthesis of amorphous inorganic solids starting from metal-organic precursors $\left(\mathrm{Si}\left(\mathrm{OCH}_{3}\right)_{4}\right.$ or $\mathrm{Si}\left(\mathrm{OC}_{2} \mathrm{H}_{5}\right)_{4}$ being the most commonly used) which undergo numerous catalytic hydrolysis and condensation reactions that can be written schematically as follow (Brinker \& Scherer, 1990; Park \& Clark, 2002):

- hydrolysis/esterification

$$
-\stackrel{\mathrm{Si}}{\mathrm{l}} \mathrm{OR}+\mathrm{H}_{2} \mathrm{O} \rightleftharpoons-\mathrm{Si}_{\mid} \mathrm{OH}+\mathrm{ROH}
$$

- $\quad$ water condensation/hydrolysis

$$
\underset{\mid}{\mid} \mathrm{Si}-\mathrm{OH}+\mathrm{HO}-\mathrm{Si}_{\mathrm{S}} \rightleftharpoons-\mathrm{Si}-\mathrm{O}-\mathrm{Si}_{\mid}+\mathrm{H}_{2} \mathrm{O}
$$

- alcohol condensation/alcoholysis

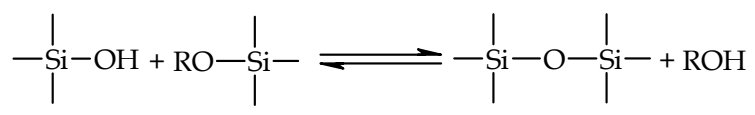

Sol-gel technique implies the silica matrix synthesis, at room temperature and mild conditions, around biomolecules or even larger biological species, without altering the biological activity (Bhatia et al., 2000; Gupta \& Chaudhury, 2007). Biomolecules like proteins, enzymes, hormones, antibodies, cell components or even viable whole cells remain active in the porous network. Smaller species from the environment may diffuse within the matrix and interact with the entrapped biomolecules (Yoo \& Lee, 2010).

This method avoids problems such as covalent modification (strong binding which can affect residues involved in the catalytic site) or desorbtion (van der Waals, hydrogen or ionic binding). Due to its inorganic nature, silica is a chemically, thermally, mechanically and biologically inert material. The high hydrophilicity and porosity make it compatible with biological species. More than that, synthesis of sol-gel materials is simple, fast and flexible (Avnir et al., 1994; Jin \& Breman, 2002; Livage et al., 2001).

The result of hydrolysis and polycondensation reactions is a colloidal sol that contains siloxane bonds (Si-O-Si network) and that, in presence of the target biomolecules or biological species, undergoes further condensation reactions till the gelation point is reached, in a time lasting from seconds to days. At the gelation point, the silica matrix forms a continuous solid throughout the whole volume, with an interstitial liquid phase, containing the biomolecules or 
biological species. The most important property of this material is its dynamic structure. The hydrolysis and condensation reactions continue as far as unreacted hydroxy or alkoxy groups are still present in the system, in the aging phase. A nano- or a mesostructured material is formed. The water and the alcohol introduced or produced can be removed stepwise, in a drying process that leads to a solid in which the pores collapse as solvent is removed. The shrinkage of the wet matrix may alter the protein. Fortunately, most applications imply function in aqueous environment so complete drying can be avoided.

The three-dimensional Si-O-Si bonds are formed around the biomolecule which, even though is trapped in the cage, remains active in the porous network. The sol-gel matrices preserve the native stability and reactivity of biological macromolecules for sensing. More than that, they can be obtained as powders, fibers, monoliths or thin films. This versatility makes them suitable for biosensing. The formation of thin films is a rather complex process. Sol viscosity, gelation time, solvent evaporation, film collapse may influence the microstructure of the thin film. This microstructure is essential for the access of small molecules and analytes. Dip-coating or spin-coating may be used to obtain thin films with reproducible properties.

Metal alkoxides are the typical precursors for sol-gel technology. The development of silica based sol-gels in the materials sciences is mainly based on tetraalkoxysilanes $\mathrm{Si}(\mathrm{OR})_{4}$ or organoalkoxysilanes $\mathrm{R}_{(4-\mathrm{x})} \mathrm{Si}(\mathrm{OR})_{x}$, where $\mathrm{x}=1-4$ and $\mathrm{R}$ is an organic residue $\left(\mathrm{R} \mathrm{CH}_{3^{-}}, \mathrm{C}_{2} \mathrm{H}_{5^{-}}\right.$, $\mathrm{C}_{6} \mathrm{H}_{5^{-}}, \mathrm{R}^{\prime}: \mathrm{CH}_{3^{-}}, \mathrm{C}_{2} \mathrm{H}_{5^{-}}, \mathrm{C}_{6} \mathrm{H}_{5^{-}}$, etc.) (Brinker \& Scherer, 1990; Gupta \& Chaudhury, 2007). Hydrolysis and condensation reactions of organoalkoxysilanes occur in a similar manner:

- hydrolysis/esterification

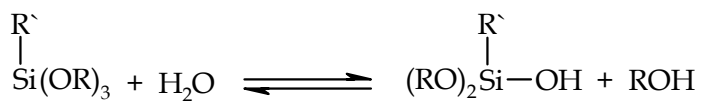

- water condensation/hydrolysis

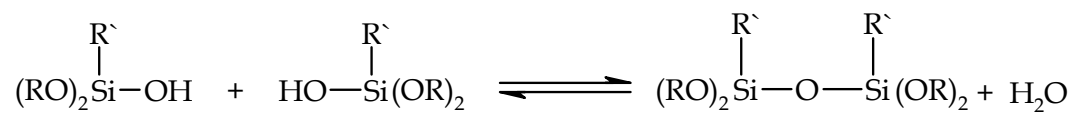

- alcohol condensation/alcoholysis

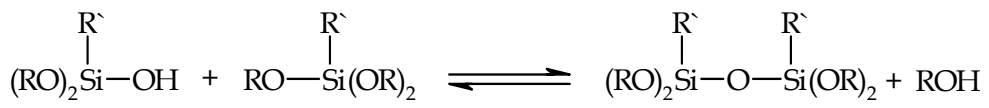

Precursors containing $\mathrm{R}^{\prime}$ hydrophobic residues modify the polymeric network. Other precursors, containing functions such as vinyl, methacryl or epoxy, may act as network forming precursors, due to their reactive monomers (Table 2).

Organically modified alkoxides act in the hydrolysis and polycondensation reactions identically with un-substituted alkoxides. Their reactivity increases in the order: TEOS < VTES < MTES. By far the most largely used precursors for the sol-gel matrixes are TMOS and TEOS. Due to their low water solubility, an alcohol is needed to avoid phase separation. Also, during the hydrolysis and polycondensation processes, an alcohol is released, which may cause enzyme inactivation. Tetrakis (2-hydroxiethyl) orthosilicate (THEOS) is a completely water soluble precursor which can avoid thermal effects or enzyme unfolding, due to biocompatibility of the ethylene glycol released in reaction (Shchipunov et al., 2004). 


\begin{tabular}{|c|c|}
\hline Network modifying precursors & Network forming precursors \\
\hline Methyltriethoxysilane (MTES) & $\begin{array}{l}\text { Metallic alkoxides } \\
\mathrm{M}(\mathrm{OEt})_{4}, \mathrm{M}=\mathrm{Si}, \mathrm{Ti}, \mathrm{Zr}\end{array}$ \\
\hline Propyltriethoxysilane (PTES) & Vinyltriethoxysilane (VTES) \\
\hline Phenyltriethoxysilane (PTES) & Methacryloxypropyltriethoxysilane \\
\hline 3-aminopropyltriethoxysilane (APTES) & 3-(Glycidoxypropyl)triethoxysilane (GPTES) \\
\hline Mercaptopropyltriethoxysilane & 3-(trimethoxysilyl)propyl acrylate \\
\hline
\end{tabular}

Table 2. Examples of network forming and modifying precursors

To make the sol-gel synthesis compatible with the biomolecules, less invasive reaction conditions are needed. Usually to avoid thermal effects, the sol is produced before the enzyme is added. TMOS derived gels shrink very much, the enzyme being physically restricted in a limited space, which leads to activity loss. Hybrid organic-inorganic matrices shrink less. The properties of sol-gel matrices (porosity, surface aria, polarity, rigidity) depend on the hydrolysis and polycondensation reactions. They are influenced by the precursors, water - precursor molar ratio, solvent, concentrations of the reaction mixture components, pressure, temperature, maturation and drying conditions and different additives, as pore forming or imprinting agents (Coradin et al., 2006).

Polymers like alginate, xanthan, gelatin, chitin, chitosan, carrageenan, hydroxyethyl cellulose, polyvinyl alcohol, polyethylene glycol, polyacrylamide, 2-hydroxyethyl methacrylate or polyethylene oxide may be added in the sol-gel matrix. In this hybrid sol-gel materials covalent, hydrogen, van der Waals bindings or electrostatic interactions may occur between the inorganic and organic components. The macromolecular additives may act as pore 
forming agents. The porosity can be tailored by using detergents, ionic liquids, crown-ethers, cyclodextrines, etc. D-glucose was used as imprinting agent, being easy to eliminate. Additionally PEG and PVA may avoid pores collapse (Avnir et al., 1994; Coradin et al., 2006).

\subsection{Glucose biosensors based on sol-gel immobilized glucose oxidase}

Enzymes applications in health care are of remarkable impact (Table 3). Among them, glucose sensing with enzymes is of tremendous importance. Blood glucose level is one of the most important parameters in clinical practice, with continuous monitoring in diabetes, as one of the most important diseases in humans. Sedentary lifestyle and bad eating habits which lead to obesity are important causes of vascular diseases. Glucose level monitoring is important also in insulin therapy, dietary regimes or hypoglycemia (Yoo \& Lee, 2010).

Glucose can be measured using three enzymes: hexokinase, glucose oxidase (GOx) and glucose-dehydrogenase (GDH). Glucose oxidase ( $\beta$-D-glucose:oxygen-1-oxidoreductase, E.C.1.1.3.4.), discovered by Muller in 1928, is the most used oxidoreductase for glucose assay. This enzyme can be isolated from algae, citrus fruits, insects, bacteria or fungi. Most studies were carried out with microbial enzymes obtained by fermentation of Aspergillus niger and Penicillum notatum strains (Turdean et al., 2005; Wilson \& Turner, 1992). Glucose oxidase has high substrate specificity for glucose, high activity, high accessibility (mainly from Aspergillus niger).

The glucose biosensor is based on the ability of glucose oxidase to catalyse the oxidation of glucose by molecular oxygen to gluconic acid and hydrogen peroxide:

$$
\begin{gathered}
\beta \text {-D-glucose }+\mathrm{O}_{2}+\mathrm{H}_{2} \mathrm{O} \stackrel{\text { Glucose oxidase }}{\longrightarrow} \text { D-gluconic acid }+\mathrm{H}_{2} \mathrm{O}_{2} \\
\mathrm{H}_{2} \mathrm{O}_{2} \longrightarrow \mathrm{O}_{2}+2 \mathrm{H}^{+}+2 \mathrm{e}^{-}
\end{gathered}
$$

Glucose oxidase, a flavoprotein, as a redox reaction catalyst, requires a cofactor, FAD, which is regenerated by reaction with molecular oxygen, so no cofactor regeneration is needed.

The molecular oxygen consumption or the hydrogen peroxide production during the reaction is proportional with the glucose concentration. Hydrogen peroxide is oxidized at the electrode and the electron exchange between the enzyme and the electrode (the current generated) can be detected amperometrically. On the other hand, D-gluconic acid is released in the reaction, the $\mathrm{pH}$ decay being proportional with the glucose consumption. The $\mathrm{pH}$ can be monitored by potentiometric measurements, with a $\mathrm{pH}$-sensitive glass electrode. In both cases, the enzyme has to be attached to the sensitive surface of the electrode. So, the electrode has a double function: to support the enzyme and to detect a change of a parameter (molecular oxygen consumption, $\mathrm{pH}$ change) related to the change of the analyte concentration. Alternatively, the enzyme can be incorporated in the electrode (carbon paste). Three generations of glucose biosensors are described in literature. While $\mathrm{H}_{2} \mathrm{O}_{2}$ and $\mathrm{D}$ gluconic acid production can be monitored potentiometrically, the oxygen consumption can be measured amperometrically, for example with a Pt electrode, similarly with the oxygen electrode invented by Clark in 1962 (first-generation biosensors). Also, a redox mediator can be used to facilitate electrons transfer from GOx to electrode surface. A variety of mediators were used to enhance biosensor performances: ferrocenes, ferricyanides, quinines and their derivatives, dyes, conducting redox hydrogels, nanomaterials (second-generation biosensors). 


\begin{tabular}{|c|c|c|}
\hline \multirow[t]{2}{*}{ Enzyme } & \multirow{2}{*}{$\begin{array}{c}\text { E.C. } \\
\text { number }\end{array}$} & Application \\
\hline & & Markers for disease \\
\hline $\begin{array}{l}\text { Acetyl cholinesterase } \\
\text { (AChE) }\end{array}$ & E.C.3.1.1.7 & important in controlling certain nerve impulses \\
\hline Creatine kinase (CK) & E.C.2.7.3.2 & indicates a stroke or a brain tumour (heart attack) \\
\hline \multirow{2}{*}{$\begin{array}{l}\text { Lactate dehydrogenase } \\
(\mathrm{LDH})\end{array}$} & E.C.1.1.1.27 & indicates a tissue damage (heart attack) \\
\hline & & Clinical diagnoses of diseases \\
\hline $\begin{array}{l}\text { Alanine } \\
\text { aminotransferase (ALT) }\end{array}$ & E.C.2.6.1.2 & sensitive liver-specific indicator of damage \\
\hline $\begin{array}{l}\text { Alkaline phosphatase } \\
\text { (ALP) }\end{array}$ & E.C.3.1.3.1 & involved in bone and hepatobiliary diseases \\
\hline $\begin{array}{l}\text { Aspartate } \\
\text { aminotransferase (AST) }\end{array}$ & E.C.2.6.1.1 & $\begin{array}{l}\text { myocardial, hepatic parenchymal and muscle } \\
\text { diseases in humans and animals }\end{array}$ \\
\hline $\begin{array}{l}\text { Butylcholinesterase } \\
\text { (ButChE) }\end{array}$ & E.C.3.1.1.8 & $\begin{array}{l}\text { acute infection, muscular dystrophy, chronic } \\
\text { renal disease and pregnancy, insecticide } \\
\text { intoxication }\end{array}$ \\
\hline Creatine kinase (CK) & E.C.2.7.3.2 & myocardial infarction and muscle diseases \\
\hline $\begin{array}{l}\text { Lactate dehydrogenases } \\
\text { (LDH) }\end{array}$ & E.C.1.1.1.27 & $\begin{array}{l}\text { myocardial infarction, haemolysis and liver } \\
\text { disease }\end{array}$ \\
\hline $\begin{array}{l}\text { Serum pancreatic lipases } \\
\text { (triacylglycerol lipase) }\end{array}$ & E.C.3.1.1.3 & pancreatitis and hepatobiliary disease \\
\hline $\begin{array}{l}\text { Sorbitol dehydrogenase } \\
\text { (SDH) }\end{array}$ & E.C.1.1.1.14 & hepatic injury \\
\hline Trypsin & E.C.3.4.21.4 & pancreatitis, biliary tract and fibrocystic diseases \\
\hline a-Amylase (AMY) & E.C.3.2.1.1 & diagnostic aid for pancreatitis \\
\hline $\begin{array}{l}\text { y-Glutamyltransferase } \\
\text { (GGT) }\end{array}$ & E.C.2.3.2.2 & hepatobiliary disease and alcoholism \\
\hline \multirow[t]{2}{*}{ Acid phosphatase $(\mathrm{ACP})$} & E.C.3.1.3.2 & prostate carcinoma \\
\hline & & Therapeutic agents \\
\hline \multirow[t]{2}{*}{ Asparaginase } & E.C. 3.5.1.1 & leukaemia \\
\hline & & Clinical chemistry \\
\hline Glucose oxidase & E.C.1.1.3.4 & D-glucose content; diagnosis of diabetes mellitus \\
\hline Lactate dehydrogenase & E.C.1.1.1.27 & blood lactate and pyruvate \\
\hline Urease & E.C.3.5.1.5 & blood urea \\
\hline Cholesterol oxidase & E.C.1.1.3.6 & blood cholesterol \\
\hline \multirow[t]{2}{*}{ Luciferase } & EC.1.13.12.7 & $\begin{array}{l}\text { adenosine triphosphate (ATP) (e.g. from blood } \\
\text { platelets); } \mathrm{Mg}^{2+} \text { concentration }\end{array}$ \\
\hline & & Immunoassays \\
\hline Horseradish peroxidise & E.C.1.11.1.7 & \multirow[t]{2}{*}{ enzyme-linked immunosorbent assay (ELISA) } \\
\hline Alkaline phosphatise & E.C.3.1.3.1 & \\
\hline
\end{tabular}

Table 3. Enzymes applications in health care (Soetan et al., 2010) 
Conducting organic polymers, conducting organic salts, polypyrrole based electrodes were used in the third generation of glucose biosensors, which allowed a direct transfer of electrons between enzyme and electrode (Yoo \& Lee, 2010). Sol-gel technology may be present in all three biosensors generations. Some characteristic examples on how sol-gel immobilization is involved in several enzyme biosensors construction are shown in Table 4.

Both largely used amperometric biosensors or less extended potentiometric biosensors have yet to pass efficient, long term functioning exams in time. The main problems that have to be overcome:

a. Amperometric biosensors

The high polarizing voltage needed may cause interferences. Substances such as ascorbic acid, uric acid or other drugs, often present in biological fluids, are oxidized at high potential. To avoid this, either redox mediators or modified electrodes are used.

b. Potentiometric biosensors

The enzymatic reaction is based on oxidation of $\beta$-D-glucose to D-glucono- $\beta$-lactone catalyzed by glucose oxidase. Three inherent problems may occur. First, molecular oxygen is the electron acceptor which produces hydrogen peroxide as product. But, in biological fluids, the dissolved oxygen concentration controls the glucose detection limit. Second, potentiometric biosensors detect the hydrogen ions produced by the dissociation of Dgluconic acid. Its low dissociation constant is responsible for the low sensitivity of the method. Third, product inhibition by hydrogen peroxide on enzyme activity may occur. Though simple and economical, potentiometric biosensors have to find solutions for all this problems (better $\mathrm{pH}$ sensors and immobilization method, solutions to overcome oxygen deficiency and enzyme inhibition) (Liao et al., 2007).

\section{New trends in sol-gel immobilized glucose oxidase biosensors}

Recent studies are focused now on nano- and bio-nanomaterials. Enzyme immobilization using methods based on sol-gel combined with smart materials (carbon nanotubes, conducting polymers, metal or metal oxide nanoparticles, self assembled systems) could be an interesting alternative (Table 4 ).

a. Conducting polymers

New generation of mediator-free (reagentless) biosensors based on direct electron transfer uses immobilized enzymes on conducting substrates. Many methods and materials have been used to promote the electron transfer from oxidoreductases directly to the electrode surface. Among them, conducting biopolymers, nanostructures combined with sol-gel matrices are included. Due to their conductivity and electroactivity, they may act as electrons mediators between enzyme active site and electrode surface, leading to short response time and high operational and storage stability (Teles \& Fonseca, 2008).

Silica conducting polymer hybrids may be synthesized by co-condensation of organosilanes, post-coupling of functional molecules on silica surface or non-covalent binding of different species. A strategy for silica conducting polymer hybrids synthesis is to modify silica with organic functional moieties and then, these functionalized precursors may react to form polymer chains in the pores or channels of the silica.

Polyaniline (PA) is one of the most important conducting polymers. A glucose biosensor (PA-GOx/Pt) modified using a sol-gel precursor containing sulphur ((3-mercaptopropyl) trimethoxysilane, MPTMS) has good analytical characteristics and does not respond to interferences (Yang et al., 2008). 


\begin{tabular}{|c|c|c|c|}
\hline Sol-gel immobilization method & Enzyme(s) & Analyte & Ref. \\
\hline TEOS derived sol-gel matrixes & Glucose oxidase & Glucose & $\begin{array}{l}\text { Chang et al., } \\
2010\end{array}$ \\
\hline $\begin{array}{l}\text { Single TEOS sol-gel matrix } \\
\text { coupled to } N \text {-Acetyl-3,7- } \\
\text { dihydroxy-phenoxazine }\end{array}$ & $\begin{array}{l}\text { Horseradish peroxidase } \\
\text { Superoxide dismutase } \\
\text { Xanthine oxidase }\end{array}$ & Xanthyne & $\begin{array}{l}\text { Salinas- } \\
\text { Castillo et } \\
\text { al., } 2008\end{array}$ \\
\hline $\begin{array}{l}\text { Thin sol-gel film derived from } \\
\text { TEOS sol-gel system }\end{array}$ & Acetylcholinesterase & $\begin{array}{l}\text { Organophos- } \\
\text { phorous } \\
\text { pesticides }\end{array}$ & $\begin{array}{l}\text { Anitha et } \\
\text { al., } 2004\end{array}$ \\
\hline $\begin{array}{l}\text { MTOS sol-gel chitosan/silica and } \\
\text { MWCNT organic-inorganic hybrid } \\
\text { composite film }\end{array}$ & Chlolesterol oxidase & Cholesterol & $\begin{array}{l}\text { Tan et al., } \\
2005\end{array}$ \\
\hline $\begin{array}{l}\text { TMOS sol-gel/chitosan inorganic- } \\
\text { organic hybrid film }\end{array}$ & Horseradish peroxidase & $\mathrm{H}_{2} \mathrm{O}_{2}$ & $\begin{array}{l}\text { Miao et al., } \\
2001\end{array}$ \\
\hline $\begin{array}{l}\text { One-pot covalent immobilization } \\
\text { in a biocompatible hybrid matrix } \\
\text { based on GPTMS and chitosan }\end{array}$ & Horseradish peroxidase & $\mathrm{H}_{2} \mathrm{O}_{2}$ & $\begin{array}{l}\text { Li et al., } \\
2009\end{array}$ \\
\hline $\begin{array}{l}\text { Sol-gel organic-inorganic hybrid } \\
\text { material based on chitosan and } \\
\text { THEOS }\end{array}$ & Horseradish peroxidase & $\mathrm{H}_{2} \mathrm{O}_{2}$ & $\begin{array}{l}\text { Wang et al., } \\
2006\end{array}$ \\
\hline $\begin{array}{l}\text { Chitosan/silica sol-gel hybrid } \\
\text { membranes obtained by cross- } \\
\text { linking of APTES with chitosan }\end{array}$ & Horseradish peroxidase & $\mathrm{H}_{2} \mathrm{O}_{2}$ & $\begin{array}{l}\text { Li et al., } \\
2008\end{array}$ \\
\hline $\begin{array}{l}\text { Immobilization in multi-walled } \\
\text { carbon nanotubes (MWCNTs) } \\
\text { embedded in silica matrix (TEOS) }\end{array}$ & Urease & Urea & $\begin{array}{l}\text { Ahuja et al., } \\
2011\end{array}$ \\
\hline $\begin{array}{l}\text { Immobilization in MTOS sol-gel } \\
\text { chitosan/silica hybrid composite } \\
\text { film }\end{array}$ & Glucose oxidase & Glucose & $\begin{array}{l}\text { Tan et al., } \\
2005\end{array}$ \\
\hline $\begin{array}{l}\text { Encapsulation within sol-gel } \\
\text { matrix based on (3-aminopropyl) } \\
\text { triethoxy silane, 2-(3,4- } \\
\text { epoxycyclohexyl)-ethyltrimetoxy } \\
\text { silane }\end{array}$ & Glucose oxidase & Glucose & $\begin{array}{l}\text { Couto et al., } \\
2002\end{array}$ \\
\hline $\begin{array}{l}\text { Immobilization in sol-gel films } \\
\text { obtained from (3-aminopropyl) } \\
\text { trimethoxysilane, 2-(3,4-epoxy- } \\
\text { cyclohexyl) ethyl-trimethoxysilane }\end{array}$ & Lactate oxidase & Lactate & $\begin{array}{l}\text { Gomes et } \\
\text { al., } 2007\end{array}$ \\
\hline $\begin{array}{l}\text { Covalent immobilization onto } \\
\text { TEOS sol-gel films }\end{array}$ & $\begin{array}{l}\text { Cholesterol esterase, } \\
\text { cholesterol oxidase }\end{array}$ & Cholesterol & $\begin{array}{l}\text { Singh et al., } \\
2007\end{array}$ \\
\hline $\begin{array}{l}\text { Immobilization of the enzyme in a } \\
\text { TMOS derived silica sol-gel matrix }\end{array}$ & Yeast hexokinase & Glucose & $\begin{array}{l}\text { Hussain et } \\
\text { al., } 2005\end{array}$ \\
\hline
\end{tabular}

Table 4. Sol-gel technique adapted to different enzyme biosensors 
A mediatorless bi-enzymatic amperometric glucose biosensor with two enzymes (GOx and horseradish peroxidase (HRP)) co-immobilized into porous silica-polyaniline hybrid composite was obtained by electrochemical polymerization of $\mathrm{N}$ [3-(trimethoxysilyl) propyl]aniline (TMSPA). The method revealed the advantages of using both conducting polymers and silica matrices synergistically in one-pot polymerization and immobilization (Manesh, 2010). The co-immobilization of both GOx and HRP, which acts in cascade, allows both a glucose measurement that avoids interferences and a signal amplification that increases biosensor efficiency.

b. Carbon nanotubes

In the last 20 years, carbon nanotubes have been a subject of intense studies. Carbon nanotubes (CNT) are carbon cylinders obtained by folding of graphite sheets in single (single-walled carbon nanotubes (SWCNT)) or several coaxial shells (multi-walled carbon nanotubes (MWCNT)). SWCNT and MWCNT have found important applications in biosensing due to some valuable properties, which make them compatible with sensing and biomolecules: ordered nanostructure, capacity to be functionalized with reactive groups and to link biomolecules and, very important in sensing, enhancement of electron transfer from enzyme to electrode. MWCNT were used in hybrid organic-inorganic matrices combined with sol-gel and other materials, in sandwich-type structures (Ahuja et al., 2011; Kang et al., 2008; Mugumura, 2010).

c. Metal nanoparticles and self-assembled systems

Since 1970s, we are witnesses of a rapid growth in nanocience interest for metal nanoparticles, such as $\mathrm{Au}, \mathrm{Pt}, \mathrm{Ag}, \mathrm{Cu}$, due to their enormous potential applications in catalysis, chemical sensors and biosensors. The biocompatibility of metal nanoparticles is based on their property to bind different ligands which, at their turn, can bind different biomolecules including enzymes. These nanoparticles have special electronic and photonic properties which make them extremely suitable in sensing.

Self-assembled systems are used in simple and versatile procedures to immobilize enzymes on metal or metal oxide surfaces. Organoalkoxysilanes or organochlorosilanes are able to undergo processes of self-assembly on glass, silicon or alumina surfaces. Sulphur containing molecules have a special well-known affinity to noble metal surfaces. Sulphur containing alkoxysilanes can be used as sol-gel precursors to facilitate the binding of not only enzymes but also nanoparticles and redox active species to surfaces of $\mathrm{Pt}, \mathrm{Au}, \mathrm{Cu}$ or glassy carbon.

Biosensors can be fabricated by means of self-assembled double-layer networks obtained from (3-mercaptopropyl)-trimethoxysilane (MPS) polymerized on gold electrode. Then, gold nanoparticles are attached by chemosorbtion on the double-layer polymer-gold electrode and, finally, GOx is bound to gold nanoparticles. Due to very low background current, such biosensors exhibit high sensitivity and short response time. The biosensors show a linear dependence at very low glucose concentrations and have a very low detection limit $\left(1 \times 10^{-10}\right.$ $\mathrm{M})$. No interferences are observed. The performances of such biosensors may be explained considering that the nanoparticle - MPS network produces an increased surface area, thus increasing the enzyme loading (Barbadillo et al., 2009; Zhong et al., 2005).

\section{Conclusions}

Research for advanced technologies, including highly efficient enzymes and immobilization strategies, based on new materials and improved electrodes continue to be performed. 
Future trends in the design of robust biological sensors should include new goals such as:

1. Research for new strains to produce more versatile enzymes with improved compatibility, operational activity and stability.

2. A deeper understanding of matrix-enzyme interaction, protein folding/unfolding and mobility phenomena to prevent inactivation. Other goals are: a tight and more specific bond of enzyme to matrix, a more tunable pore size distribution, new matrices, with improved properties, reduced diffusional barriers and minimal enzyme leaching to obtain an efficient and fast response from an operationally stable system.

3. New electrodes with enhanced analytical characteristics (high operational stability and sensibility, long life-time and low detection limit), active in hostile environment. High rate response and quick electron transfer from the enzyme to the transducer are problems that still wait for better solutions.

4. Improved immobilization methods for enzymes, a more efficient attachment of the enzyme - matrix assembly to the physical transducer, considering that the matrix is the key link between enzyme and transducer. A new view of geometry at nano and micro scale, to facilitate a better link among biocatalyst, matrix and transducer, based on biocompatibility.

5. Better non-invasive, portable settings for continuous in vivo monitoring. Miniaturization, biocompatibility, long term stability, specificity, and, first of all, higher accuracy are needed.

Due to their excellent biocompatibility, silica matrices may contribute to the development of new applications for more specific biosensing devices.

\section{References}

Ahuja,T.; Kumar, D.; Singh, N.; Biradar, A. M. \& Rajesh (2011). Potentiometric urea biosensor based on multi-walled carbon nanotubes (MWCNTs)/silica composite material, Mater. Sci. Eng. C 31 (2) 90-94.

Anitha, K.; Mohan, S.V. \& Reddy, S.J. (2004). Development of acetylcholinesterase silica solgel immobilized biosensor-an application towards oxydemeton methyl detection, Biosens. Bioelectron., 20 (4) 848-856.

Avnir, D.; Braun, S.; Lev, O. \& Ottolenghi M. (1994). Enzymes and other proteins entrapped in sol-gel materials, Chem. Mater. 6, 1605-1614.

Barbadillo, M.; Casero, E.; Petit-Dominguez, M. D.; Vazquez, L., Pariente, F. \& Lorenzo, E. (2009). Gold nanoparticles-induced enhancement of the analytical response of an electrochemical biosensor based on an organic-inorganic hybrid composite material, Talanta 80 (2), 797 - 802.

Belkin, S. (2003). Microbial whole-cell sensing systems of environmental pollutants, Curr. Opin. Microbiol. 6 (3), 206-212.

Bergveld, P. (1996). The future of biosensors, Sensors and Actuators A: Physical, 56 (1-2) 65-73.

Bhatia, R.B.; Brinker, C.J.; Gupta, A.K. \& Singh, A.K. (2000). Aqueous sol-gel process for protein encapsulation, Chem. Mater., 12 (8), 2434-2441.

Bickerstaff, G. F. (1997), Immobilization of Enzymes and Cells, 2nd Ed., Humana Press, New Jersey, ISBN 0-89603-386-4.

Bizerea-Spiridon, O.; Vlad-Oros, B.; Preda, G. \& Vintilă, M. (2010a). Studies regarding the membranous support of a glucose biosensor based on GOx, Animal Sciences and Biotechnologies, 43 (1), 354-357. 
Bizerea-Spiridon, O.; Vlad-Oros, B.; Preda, G. \& Vintilă, M. (2010b). The optimal composition of PVA membranar support of a glucose biosensor based on GOx, Annals of West University of Timişoara, Series of Chemistry, 19 (1), 97-104.

Brinker, C. J. \& Scherer, G. W. (1990). Sol Gel Science. The Physics and Chemistry of Sol-Gel Processing, Academic Press, Boston.

Castillo, J.; Gáspár, S.; Leth, S.; Niculescu, M.; Mortari, A.; Bontidean, I.; Soukharev, V.; Dorneanu, S. A.; Ryabov, A. D. \& Csöregi, E. (2004). Biosensors for life quality. Design, development and applications, Sensor Actuat B-Chem., 102 (2), 179-194.

Chang, G.; Tatsu, Y.; Goto, T.; Imaishi, H.\& Morigaki, K. (2010). Glucose concentration determination based on silica sol-gel encapsulated glucose oxidase optical biosensor arrays, Talanta 83 (1) 61-65.

Chaplin, M.\& Bucke, C. (1990). Enzyme Technology, Cambridge University Press, Cambridge, ISBN 0521344298.

Chibata, I. (1978) in Immobilized Enzymes, Ed. I. Chibata, John Wiley, New York, 1-73.

Coradin, T.; Allouche, J.; Boissière, M. \& Livage, J. (2006). Sol-gel biopolymer/silica nanocomposites in biotechnology, Curr. Nanosci., 2, 219-230.

Couto, C.M.C.M.; Araujo, A. N.; Montenegro, M. C. B. S. M.; Rohwedder, J.; Raimundo, I. \& Pasquini, C. (2002). Application of amperometric sol-gel biosensor to flow injection determination of glucose, Talanta 56 (6) 997-1003.

de Marcos, S.; Galindo, J.; Sierra, J. F.; Galban, J. \& Castillo, J. R. (1999). An optical glucose biosensor based on derived glucose oxidase immobilised onto a sol-gel matrix, Sensor Actuat B-Chem., 57 (1-3), 227 - 232.

Faber, K., (2000). Biotransformation in Organic Chemistry, $4^{\text {th }}$ Ed., Springer, Berlin, 21.

Gill, I. \& Ballesteros, A. (2000). Bioencapsulation within synthetic polymers (Part 1): sol-gel encapsulated biologicals, Trends Biotechnol. 18, 282-296.

Gomes, S.P.; Odlozilikova, M.; Almeida, M. G.; Araujo,A. N.; Couto, C.M.C.M. \& Montenegro, M. C. B. S. M. (2007). Application of lactate amperometric sol-gel biosensor to sequential injection determination of 1-lactate, J. Pharmaceut. Biomed. 43(4) 1376-1381.

Gupta, R. \& Chaudhury, N.K. (2007). Entrapment of biomolecules in sol-gel matrix for applications in biosensors: Problems and future prospects, Biosens. Bioelectron. 22, 2387-2399.

Hussain, F.; Birch, D. J. S. \& Pickup, J. C. (2005). Glucose sensing based on the intrinsic fluorescence of sol-gel immobilized yeast hexokinase, Anal.Biochem. 339 (1) 137-143.

Ivnitski, D.; Abdel-Hamid, I.; Atanasov, P.; Wilkins, E. \& Stricker, S. (2000). Application of electrochemical biosensors for detection of food pathogenic bacteria, Electroanalysis, 12 (5), 317-325.

Jin, W. \& Breman, J. D. (2002). Properties and applications of proteins encapsulated within sol - gel derived materials, Anal. Chim. Acta, 461, 1-36.

Justino, C .I. L.; Rocha-Santos, T. A. \& Duarte, A. C (2010). Review of analytical figures of merit of sensors and biosensors, TRAC - Trend. Anal. Chem., 29 (10), 1172-1183.

Kang, X.; Mai, Z.; Zou, X.; Cai, P. \& Mo, J. (2008). Glucose biosensors based on platinum nanoparticles-deposited carbon nanotubes in sol-gel chitosan/silica hybrid, Talanta $74(4), 879-886$.

Kennedy, J. F. \& Cabral, J. M. S. (1987) in Biotechnology, vol. 7a, Enzyme Technology, Ed. J. F. Kennedy, VCH, Weinheim, 349-400.

Khan, A. A. \& Alzohairy, M. A. (2010). Recent Advances and applicationa of immobilized enzyme technologies, Res. J. Biol. Sci., 5(8), 565-575. 
Kim J.; Grate J. W. \& Wang P. (2006). Nanostructures for Enzyme Stabilization, Chem. Eng. Sci. 61, 1017-1026.

Krajewska, B. (2004) Application of chitin- and chitosan-based materials for enzyme immobilizations: a review, Enzyme Microb. Technol., 35, 126-139.

Kunzelmann, U. \& Bottcher, H. (1997). Biosensor properties of glucose oxidase immobilized within $\mathrm{SiO}_{2}$ gels, Sensor Actuat. B-Chem., 39(1-3), 222 - 228.

Lalonde J. \& Margolin A. (2002) in Enzyme Catalysis in Organic Synthesis, Ed. Drauz K. \& Waldmann H., 2nd Ed., Wiley-VCH, Weinheim, 163-185.

Lazcka, O.; Del Campo, F. J. \& Munoz, F. X. (2007). Pathogen detection: a perspective of traditional methods and biosensors, Biosens. Bioelectron., 22, 1205-1217.

Lei, Y.; Chen, W. \& Mulchandani, A. (2006). Microbial biosensors, Anal. Chim. Acta, 568 (1-2), 200-210.

Liao, C.-W.; Chou, J.-C.; Sun, T.-P.; Hsiung, S.-K.; Hsieh, J.-H. (2007). Preliminary investigations on glucose biosensor based on the potentiometric principle, Sensor Actuat B-Chem 123, 720-726.

Li, B. \& Takahashi, H. (2000). New immobilization method for enzyme stabilization involving a mesoporous material and an organic/inorganic hybrid gel, Biotechnol. Lett., 22, 1953-1958

Li, F.; Chen,W.; Tang,C. \& Zhang, S. (2009). Development of hydrogen peroxide biosensor based on in situ covalent immobilization of horseradish peroxidase by one-pot polysaccharide-incorporated sol-gel process, Talanta 77(4), 1304-1308.

Li, W.; Yuan, R.; Chai,Y.; Zhou, L.; Chen, S. \& Li,N. (2008). Immobilization of horseradish peroxidase on chitosan/silica sol-gel hybrid membranes for the preparation of hydrogen peroxide biosensor, J. Biochem. Biophys. Methods 70 (6), 830-837.

Livage, J.; Coradin, T. \& Roux, C. (2001). Encapsulation of biomolecules in silica gels, J. Phys.: Condens. Matter. 13, 673-691.

Manesh, K. M.; Santhosh, P.; Uthayakumar, S.; Gopalan, A. I. \& Lee, K. P. (2010). One-pot construction of mediatorless bi-enzymatic glucose biosensor based on organicinorganic hybrid, Biosens. Bioelectron. 25(7), 1579 - 1586.

Mateo, C.; Palomo, J. M.; Fernandez-Lorente, G.; Guisan , J. M. \& Fernandez-Lafuente, R. (2007). Improvement of enzyme activity, stability and selectivity via immobilization techniques, Enzyme Microb. Technol., 40, 1451-1463.

Matrubutham, U.\& Sayler, G.S. (1998). Microbial biosensors based on optical detection, in Enzyme and Microbial Biosensors: Techniques and Protocols, Methods in Biotechnology, Vol. 6, Mulchandani, A., Rogers K. R., Eds., Humana Press, Totowa, 249-256.

Mello, L. D. \& Kubota, L. T. (2002). Analytical, nutritional and clinical methods - review of the use of biosensors as analytical tools in the food and drink industries, Food Chem. 77(2), 237-256.

Miao,Y. \& Tan, S.N. (2001). Amperometric hydrogen peroxide biosensor with silica solgel/chitosan film as immobilization matrix, Anal. Chim. Acta, 437 (1) 87-93.

Mugumura, H. (2010). Amperometric Biosensor Based on Carbon nanotube and Plasma Polymer, in Biosensors, Ed. Serra, P.A., INTECH, 47-72, ISBN 978-953-7619-99-2.

Murty, V. R.; Bhat, J. \& Muniswaran, P. K. A. (2002). Hydrolysis of oils by using immobilized lipase enzyme: a review, Biotechnol. Bioprocess Eng., 7, 57-66.

Nayak, M.; Kotian, A.; Marathe, S. \& Chakravortty, D. (2009). Detection of microorganisms using biosensors - A smarter way towards detection techniques, Biosens. Bioelectron., 25 (4) 661-667. 
Newman, J.D.; Turner, A.P. (2005). Home blood glucose biosensors: a commercial perspective, Biosens. Bioelectron., 20, 2435-2453.

Oh, B. K.; Lee, W.; Chun, B. S.; Bae,Y.M.; Lee, W. H. \& Choi, J. W. (2005). The fabrication of protein chip based on surface plasmon resonance for detection of pathogens, Biosens. Bioelectron., 20 (9) 1847-1850.

Park, C. B. \& Clark, D. S. (2002). Sol-gel encapsulated enzyme arrays for high-throughput screening of biocatalytic activity, Biotechnol. Bioeng., 78 (2), 229-235.

Petkar, M.; Lali, A.; Caimi, P. \& Daminati, M. (2006). Immobilization of lipases for nonaqueous synthesis, J. Mol. Catal., B Enzym., 39, 83-90.

Radke, S. M. \& Alocilja, E. C. (2005). A high density microelectrode array biosensor for detection of E. coli O157:H7, Biosens. Bioelectron., 20 (8) 1662-1667.

Reetz, M. T.; Wenkel, R. \& Avnir, D. (2000). Entrapment of lipases in hydrophobic sol-gel materials: Efficient heterogenous biocatalysts in aqueous medium, Synthesis 6, 781783.

Reetz, M. T.; Tielmann, P.; Wiesenhöfer, W.; Könen, W. \& Zonta, A. (2003). Second Generation Sol - Gel Encapsulated Lipases: Robust Heterogeneus Biocatalysts, Adv. Synt. Catal., 345, 717-728.

Rodriguez-Mozaz, S.; López de Alda, M. J.; Marco, M. P. \& Barceló, D. (2005). Biosensors for environmental monitoring. A global perspective, Talanta, 65 (2) 291-297.

Rodriguez-Mozaz, S.; López de Alda, M. J.; Marco, M. P. \& Barceló, D. (2006). Biosensors as useful tools for environmental analysis and monitoring, Anal. Bioanal. Chem. 386 (4) 1025-1041.

Rogers, K. R. (2006). Recent advances in biosensor techniques for environmental monitoring, Anal. Chim. Acta, 568, (1-2) 222-231.

Rogers, K. R. \& Mascini, M. (2009). Biosensors for Analytical Monitoring - General Introduction and Review, in US Environmental Protection Agency, 05.01.2011, http://www.epa.gov/heasd/edrb/biochem/intro.html

Rothenberg G. (2008). Catalysis, Concepts and Green Applications, Wiley-VCH, Weinheim, ISBN 978-3-527-31824-7

Salinas-Castillo, A.; Pastor, I.; Mallavia, R. \& Mateo, C. R. (2008). Immobilization of a trienzymatic system in a sol-gel matrix: A new fluorescent biosensor for xanthine, Biosens. Bioelectron., 24 (4), 1053-1056.

Shchipunov, Y. A.; Karpenko, T. Y.; Bakunina, I. Y.; Burtseva, Y. V. \& Zvyagintseva T. N. (2004). A new precursor for the immobilization of enzymes inside sol-gel derived hybrid silica nanocomposites containing polysaccharides, J. Biochem. Biophys. Meth. 58 (1), 25-38.

Sheldon, R. (2007). Enzyme Immobilization: The quest for optimum performance, Adv. Synth. Catal., 349, 1289-1307.

Singh, R. P. \& Choi, J.W. (2009). Biosensors development based on potential target of conducting polymers, Sensors \& Transducers Journal, 104 (5) 1-18.

Singh, S.; Singhal, R. \& Malhotra, B. D. (2007). Immobilization of cholesterol esterase and cholesterol oxidase onto sol-gel films for application to cholesterol biosensor, Anal. Chim. Acta, 582 (2), 335-343.

Smith, J.E. (2004). Biotechnology, Cambridge University Press, Cambridge, ISBN 0521833329.

Smith, S.; Mukundan, P.; Krishna Pillai, P. \& Warrier, K. G. K. (2007). Silica-gelatin biohybrid and transparent nano-coatings through sol-gel technique, Mater. Chem. Phys. $103(2-3), 318-322$. 
Soetan, K. O.; Aiyelaagbe, O. O. \& Olaiya, C. O, (2010). A review of the biochemical, biotechnological and other applications of enzymes, Afr. J. Biotechnol., 9 (4), 382-393.

Su, L.; Jia, W.; Hou, C. \& Lei, Y. (2010). Microbial biosensors: A review, Biosens. Bioelectron., 26(5), 1788-1799.

Tan, X.; Li, M.; Cai, P.; Luo, L. \& Zou, X. (2005). An amperometric cholesterol biosensor based on multiwalled carbon nanotubes and organically modified sol-gel/chitosan hybrid composite film, Anal. Biochem. 337 (1) 111-120.

Teles, F. R. R. \& Fonseca, L. P. (2008). Applications of polymers for biomolecule immobilization in electrochemical biosensors, Mater. Sci. Eng. C 28 (8), 1530-1543.

Thévenot, D. R.; Toth, K.; Durst, R. A. \& Wilson, G. S.. (1999). Electrochemical biosensors: Recommended definitions and classification (Technical Report), Pure Appl. Chem. 71 (12), 2333-2348.

Tothill, I. E. (2009). Biosensors for cancer markers diagnosis, Seminars in Cell \& Developmental Biology, 20 (1), 55-62.

Turdean, G. L.; Stanca, S. E. \& Popescu, I. C. (2005). Biosenzori Amperometrici. Teorie si Aplicatii, Presa Universitara Clujeana, Cluj-Napoca, 5 - 242, ISBN 973-610-359-5

Turner A. P. F.; Karube I. \& Wilson G. S. (1987). Biosensors: Fundamentals and Applications, Oxford University Press, Oxford, ISBN 0198547242

Ullmann's Enciclopedia of Industrial Chemistry, (1987). Ed. V, vol. A14, Ed. Kandy, L.; Rounsaville J. F.; Schutz, G., VCH, Weinheim, 1-48.

Urban, G. A. (2009). Micro- and nanobiosensors - state of the art and trends, Meas. Sci.Technol. 20 (1) 1-18.

Velusamy, V.; Arshak, K.; Korostynska, O.; Oliwa, K. \& Adley, C. (2010). An overview of foodborne pathogen detection: In the perspective of biosensors, Biotechnol. Adv. 28 (2), 232-254.

Verma, N. \& Singh, M. (2005). Biosensors for heavy metals, BioMetals, 18 (2), 121-129.

Vlad-Oros, B.; Bizerea-Spiridon, O.; Preda, G. \& Chiriac, A. (2009). Studies regarding the influence of the enzyme immobilization methods on the electrodic surface upon the performances of the glucose biosensor, Rev. Chim.-Bucharest, 60 (7), 693-698.

Wang, G. H. \& Zhang, L. M. (2006) Using novel polysaccharide-silica hybrid material to construct an amperometric biosensor for hydrogen peroxide, J. Physical Chem. B 110 (49), 24864-24868.

Wang, J. (1999). Sol-gel materials for electrochemical biosensors, Anal. Chim. Acta, 399 (1-2), 21-27.

Wilson, G. S. \& Gifford, R. (2005). Biosensors for real-time in vivo measurements, Biosens. Bioelectron., 20 (12), 2388-2403.

Wilson, R. \& Turner, A. P. F. (1992). Glucose oxidase: an ideal enzyme, Biosens. Bioelectron., 7 (3), 165-185.

Yang, Y.L.; Tseng, T.F.; Yeh, J. M.; Chen, C. A. \& Lou, S. L. (2008). Performance characteristic studies of glucose biosensors modified by (3-mercaptopropyl)trimethoxysilane solgel and non-conducting polyaniline, Sensor Actuat B-Chem. 131 (2), 533 - 540.

Yoo, E.-H. \& Lee, S.-Y. (2010). Glucose biosensors: An overview of use in clinical practice, Sensors, 10, 4558-4576.

Zhong, X.; Yuan, R.; Chai, Y.; Liu, Y.; Dai, J. \& Tang, D. (2005), Glucose biosensor based on self-assembled gold nanoparticles and double-layer 2d-network (3-mercaptopropyl)-trimethoxysilane polymer onto gold substrate, Sen. Actuators B-Chem., 104 (2), 191 - 198. 


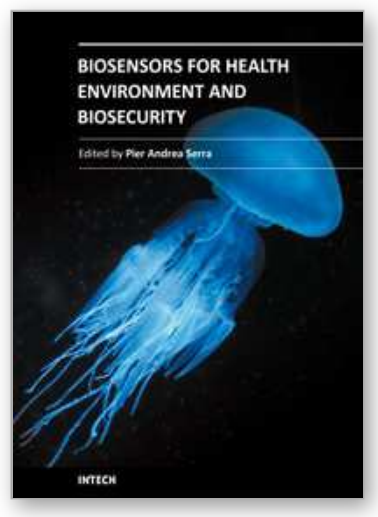

\author{
Biosensors for Health, Environment and Biosecurity \\ Edited by Prof. Pier Andrea Serra
}

ISBN 978-953-307-443-6

Hard cover, 540 pages

Publisher InTech

Published online 19, July, 2011

Published in print edition July, 2011

\begin{abstract}
A biosensor is a detecting device that combines a transducer with a biologically sensitive and selective component. Biosensors can measure compounds present in the environment, chemical processes, food and human body at low cost if compared with traditional analytical techniques. This book covers a wide range of aspects and issues related to biosensor technology, bringing together researchers from 16 different countries. The book consists of 24 chapters written by 76 authors and divided in three sections: Biosensors Technology and Materials, Biosensors for Health and Biosensors for Environment and Biosecurity.
\end{abstract}

\title{
How to reference
}

In order to correctly reference this scholarly work, feel free to copy and paste the following:

Gabriela Preda, Otilia Bizerea and Beatrice Vlad-Oros (2011). Sol-gel technology in enzymatic electrochemical biosensors for clinical analysis, Biosensors for Health, Environment and Biosecurity, Prof. Pier Andrea Serra (Ed.), ISBN: 978-953-307-443-6, InTech, Available from: http://www.intechopen.com/books/biosensors-forhealth-environment-and-biosecurity/sol-gel-technology-in-enzymatic-electrochemical-biosensors-for-clinicalanalysis

\section{INTECH}

open science | open minds

\section{InTech Europe}

University Campus STeP Ri

Slavka Krautzeka 83/A

51000 Rijeka, Croatia

Phone: +385 (51) 770447

Fax: +385 (51) 686166

www.intechopen.com

\section{InTech China}

Unit 405, Office Block, Hotel Equatorial Shanghai

No.65, Yan An Road (West), Shanghai, 200040, China

中国上海市延安西路65号上海国际贵都大饭店办公楼405单元

Phone: +86-21-62489820

Fax: +86-21-62489821 
(C) 2011 The Author(s). Licensee IntechOpen. This chapter is distributed under the terms of the Creative Commons Attribution-NonCommercialShareAlike-3.0 License, which permits use, distribution and reproduction for non-commercial purposes, provided the original is properly cited and derivative works building on this content are distributed under the same license. 